\title{
Mechanism of Riparian Vegetation Growth and Sediment Transport Interaction in Floodplain: A Dynamic Riparian Vegetation Model (DRIPVEM) Approach
}

\author{
Mahendra B. Baniya ${ }^{1,2, *}$, Takashi Asaeda ${ }^{3,4,5}$, Takeshi Fujino ${ }^{1}$, \\ Senavirathna M. D. H. Jayasanka ${ }^{1}$, Guligena Muhetaer ${ }^{1}$ and Jinghao $\mathrm{Li}^{1}$ \\ 1 Graduate School of Science and Engineering, Saitama University, 255 Shimo-okubo, Sakura-ku, \\ Saitama 338-8570, Japan; fujino@mail.saitama-u.ac.jp (T.F.); jayasanka@mail.saitama-u.ac.jp (S.M.D.H.J.); \\ gulgina1112@gmail.com (G.M.); ri.k.089@ms.saitama-u.ac.jp (J.L.) \\ 2 Provincial Government, Ministry of Physical Infrastructure Development, Pokhara 33700, Nepal \\ 3 Institute Hydro Technology Institute, 4-3-1 Shiroyama Trust Tower, Tranomon, Minato, Tokyo 105-0001, \\ Japan; asaeda@mail.saitama-u.ac.jp \\ 4 Research and Development Center, Nippon Koei, 2304 Inarihara, Tsukuba, Ibaraki 300-1259, Japan \\ 5 Institute for studies of the Global Environment, 7-1 Sophia University, Kioicho, Chiyoda, \\ Tokyo 102-0094, Japan \\ * Correspondence: baniyam57@gmail.com; Tel.: +81-048-858-9186
}

Received: 20 November 2019; Accepted: 21 December 2019; Published: 24 December 2019

\begin{abstract}
The ecological dynamics of riparian areas interact with sediment transport in river systems, which plays an active role in riparian vegetation growth in the floodplain. The fluvial dynamics, hydraulics, hydro-meteorological and geomorphological characteristics of rivers are associated with sediment transport in river systems and around the riparian area. The flood disturbance, sediment with nutrients and seeds transported by river, sediment deposition, and erosion phenomena in the floodplain change the bare land area to vegetation area and vice versa. The difference in riparian vegetation area in the river floodplain is dependent on the sediment grain size distribution which is deposited in the river floodplain. Mathematical models describing vegetation growth in a short period exist in literature, but long-term modelling and validations are still lacking. In order to cover long-term vegetation growth modelling, a Dynamic Riparian Vegetation Model (DRIPVEM) was proposed. This paper highlights the existing modelling technique of DRIPVEM coupled with a Dynamic Herbaceous Model used to establish the interactive relationship of sediment grain sizes and riparian vegetation in the floodplain.
\end{abstract}

Keywords: ecological dynamics; riparian area; sediment transport; flood disturbance; deposition and erosion; DRIPVEM

\section{Introduction}

Riparian vegetation plays a significant role in the ecological balance of a riparian area [1]. Riparian area is a transitional semiterrestrial zone extending from the edges of water bodies to the edges of upland communities and regularly interacts with river water, flow alterations, sediment, and nutrients [2-4]. Flood disturbance is one of the major causes of vegetation mortality in the riparian zone either by inundation or bank erosion [5-7]. The morphological alterations in riparian area caused by a flood event either supports or suppresses the riparian vegetation, which depends also on the sediment grain sizes deposited on the original sediment surface or exposed of previous underlying 
sediment surface [8]. The flood hydrology affects the hydrochory in the riparian area during flood time, recruits seeds, and begins colonization of trees [9]. Water is one of the major principal seed dispersal agents in the floodplain [10]. The number of seeds floating during a flood event, magnitude of the flood, duration and frequency of flood occurrence determine the seed recruitment phenomenon in the riparian area [11-13]. The area of vegetation coverage in the riparian zone is directly dependent on the availability of water, nutrients available in water and sediment before and after the flood event, and exchange of nutrients from atmosphere to the floodplain [8].

Phragmites australis, Typha spp., and Phragmites japonica are perennial plants in the riparian zone in Japanese River floodplains and have an extremely high ability to expand their territory by extending stolons [14]. The floods provide the habitat with nutrient rich water and sediment in the inundated bar. Sandy sediment sites are preferable for the growth of herbaceous plants, as moisture and nutrients in the coarse sediment layers are very limited [15-17].

The flood controlling structures such as dams and weirs control the natural flood dramatically $[5,18]$ so that the bed shear stress, specific power, and flow velocity of downstream reaches were reduced [19]. The low interacting flood events in the downstream area also curtail the sediment transport and make the river channel more stable [20]. This phenomenon gradually coarsens the downstream active riparian zone. From the sustainable reservoir management perspective, the intermittently artificial release of sediment with high nutrients deposited in reservoir through dams has been practiced in Japanese Rivers [21], and has increased the depth of fine sediment in the floodplain, which also alters the inundation pattern and sediment grain sizes in the riparian zone [22]. The released fine sediments interlocked the coarsened sediment of the bar after sedimentation in the bar, supporting the vegetation encroachment.

The sediment yield from a catchment depends on numerous parameters including topography, gradient of river, rainfall in catchment, temperature, and soil type of the catchment area $[23,24]$. Fluvial dynamics, hydraulics, hydro-meteorological and geomorphological conditions of a river determine the transport of sediment from its origin [25]. The flood events with its magnitude, duration, and frequency are associated with sediment transport [26]. The morphological characteristics of a riparian zone was altered by flooding, which triggers erosion or deposition in the floodplain [27]. The floods have an influence on recruitment as well as vegetation colonization.

The interactive parameters for riparian vegetation growth in a floodplain are illustrated Figure 1.

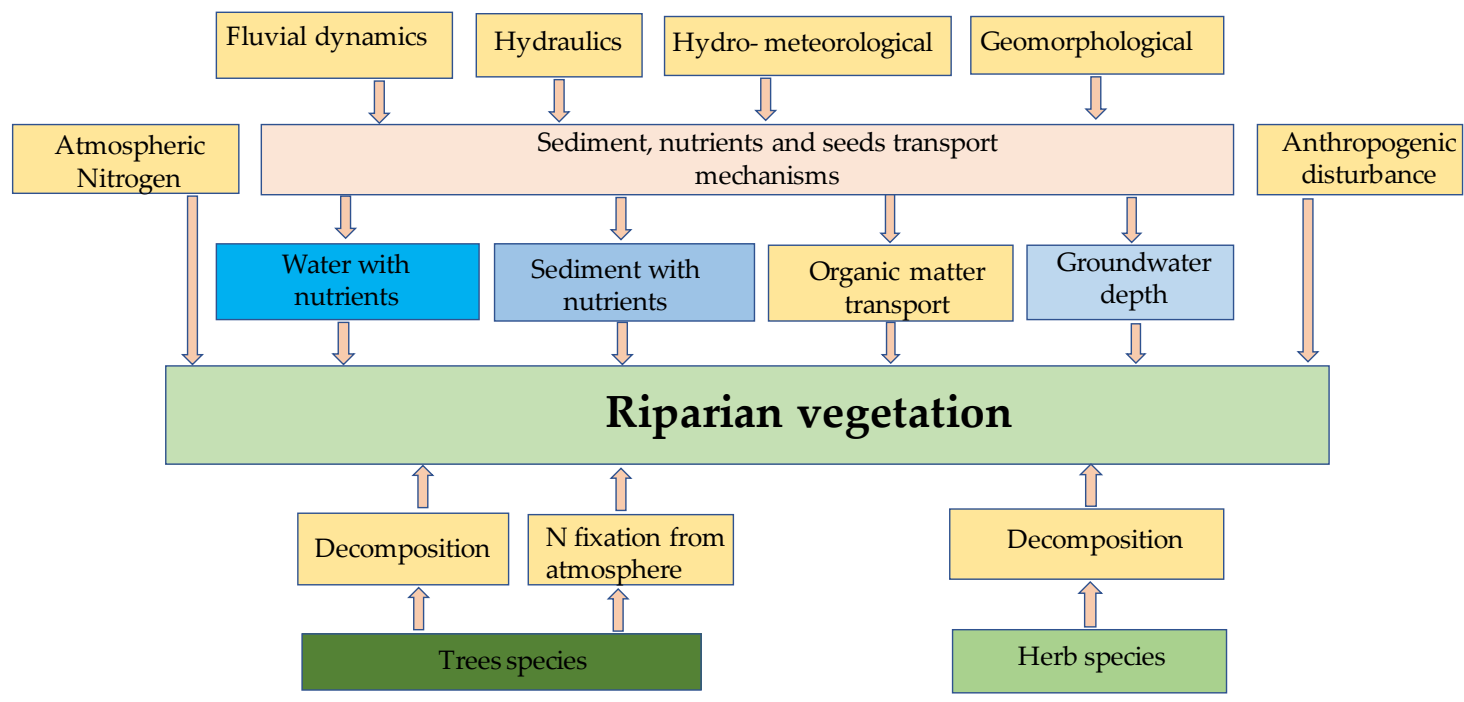

Figure 1. Interactive parameters for riparian vegetation growth in a floodplain.

The intermittent floods encountered in a floodplain alter the morphology of the riparian zone and the vegetation coverage changes by erosion or deposition of sediment [28]. The nutrients interchange from the atmosphere, human disturbance, and flooding play a role for riparian vegetation growth [29]. 
Primarily, vegetation succession in a floodplain starts from growth of herbaceous plants, which undergo senescence after completing the lifecycle, and the decomposed litter biomass become nutrients to the floodplain. The supportive role of increasing nutrients by primary succession of herbaceous plants create a favorable environment for tree recruitment in the floodplain. The decomposition of defoliated leaves of trees and aboveground biomass (AGB) and belowground biomass (BGB) of herbaceous plants also increased the nutrients level of riparian zone. The absence of large floods due to these human interventions compelled vegetation colonization in the floodplain, which removes the natural stony surface resulting a forest community.

The alterations of river hydrology and morphology after dam intervention and changes of sediment grain sizes with nutrients transport in the riparian zone make the floodplain fertile. There are numerous interactive parameters responsible for changing bare land area to vegetation areas. Numerical simulation describing riparian vegetation growth for a long period and validations are still limited in the literature [30-34]. It is difficult to address all these interacting parameters in a single mathematical model. It is important to conduct this study in floodplains to know the excessive vegetation drivers and to predict the changes in long-term riparian vegetation coverage area. The objectives of this study are to link the interacting parameters with vegetation growth in the mathematical model to elucidate the mechanisms behind riparian vegetation growth dynamics in the perspective of long-term vegetation growth modelling of a riparian area. This paper highlights the existing modelling technique of DRIPVEM $[8,9,35]$ used to establish the interactive relationship of sediment grain size and riparian vegetation in the floodplain.

\section{Materials and Methods}

\subsection{Study Site Description}

The Kuzuryu River flows through Fukui Prefecture, Japan and merges in to the sea of Japan (Figure 2a,b). The length of this river is about $116 \mathrm{~km}$. Several dams alter the river continuity. The floodplain is located about $24 \mathrm{~km}$ from the river mouth and $56 \mathrm{~km}$ downstream from the Kuzuryu River dam. The river basin has catchment area of $2930 \mathrm{~km}^{2}$. The average annual discharge of the selected study reach is about $86 \mathrm{~m}^{3} \mathrm{~s}^{-1}$ and the average annual rainfall is about $2200 \mathrm{~mm}$. The historical data sourced from Ministry of Land, Infrastructure, Transport and Tourism (MLIT), Japan recorded the maximum flood height was $7.54 \mathrm{~m}$ in October 2004 and corresponding discharge was $3221 \mathrm{~m}^{3} \mathrm{~s}^{-1}$ (http://www1.river.go.jp/) in the Kuzuryu River study reach. The floodplain $\left(36^{\circ} 06^{\prime} 23^{\prime \prime} \mathrm{N}, 136^{\circ} 16^{\prime} 06^{\prime \prime} \mathrm{E}\right)$ is about $2370 \mathrm{~m}$ long and $542 \mathrm{~m}$ wide (Figure $2 \mathrm{a}, \mathrm{b}$ ). The gradient of the study reach is $0.3 \%$.

(b)

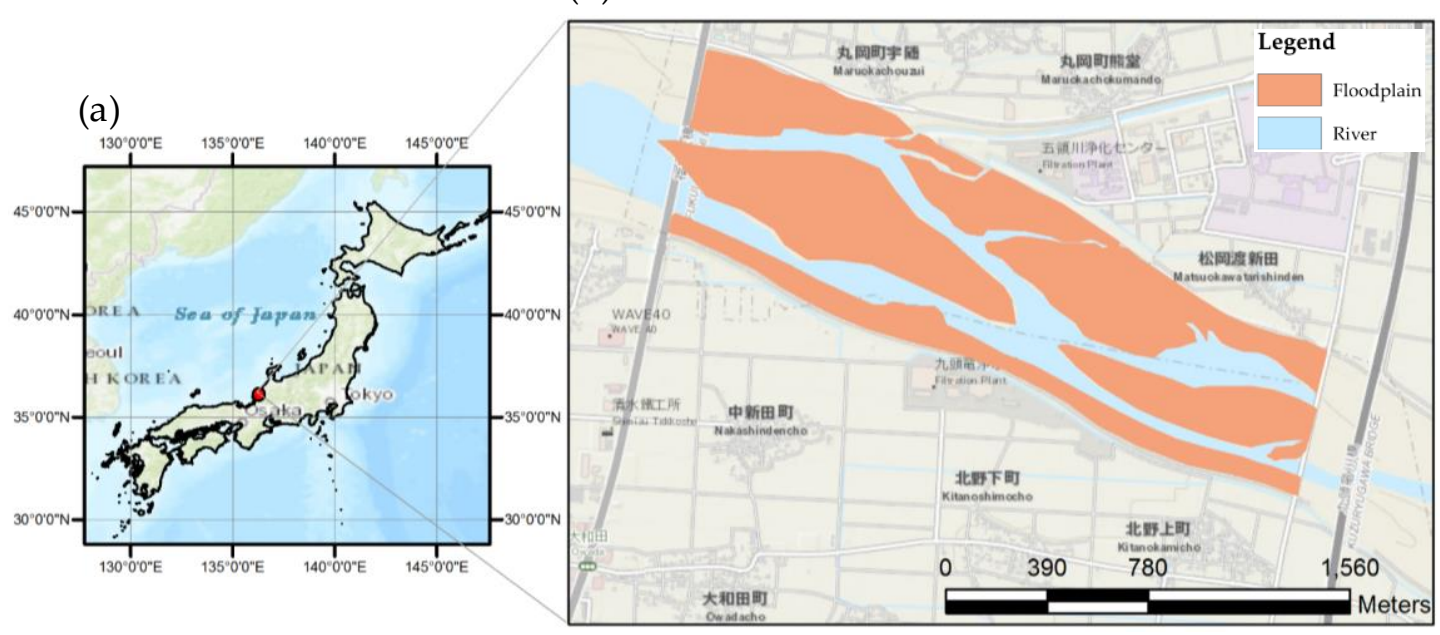

Figure 2. Location map of (a) Kuzuryu River study reach and (b) Magnified view of the study river reach floodplain. 
The main physiographic characteristics of the Kuzuryu River study reach is presented in Table 1.

Table 1. Main physiographic characteristics of study river reach.

\begin{tabular}{cc}
\hline Parameters & Descriptions \\
\hline Floodplain size & $2370 \times 542 \mathrm{~m}$ \\
\hline Mean gradient of river & $0.3 \%$ \\
\hline $\begin{array}{c}\text { Extreme flood level } \\
\text { from normal water level } \\
(0.000 \text { m elevation) }\end{array}$ & $7.54 \mathrm{~m}$ in October 2004; 6.24m in October 2002; 6.9 m and \\
$6.82 \mathrm{~m}$ in September 1998 and 1989
\end{tabular}

\subsection{Model Development}

The modelling approach is a technique frequently adopted to predict the vegetation dynamics in the riparian area which is the best tool for the long-term management perspective of riparian area. The alterations observed in riparian trees by hydro-morphological alterations and climate changes provided researchers with evidence to be used for developing numerical models [36,37]. Different mathematical and process-based approaches were used to express vegetative succession in a riparian area [38-40] and for growth and yield simulation, planning, decision making, and efficient forest management [41-43]. However, coupling of all the interacting parameters with riparian vegetation growth once at a time in a single mathematical model is a tedious task.

Most of the parameters associated with the riparian vegetation growth mechanism were clearly compiled in mathematical models for spatial distribution of herbs and trees in DRIPVEM by Asaeda [8,9]. The growth of herbaceous plants for monospecific stand in a riparian zone was described in the Dynamic Herbaceous Model [44]. The DRIPVEM coupled with a Dynamic Herbaceous Model was used to describe vegetation dynamics in the riparian zone.

\subsubsection{Dynamic Herbaceous Model for Monospecific Stand}

The herbaceous plants P. australis, Typha, and P. japonica are some of the dominant herbaceous perennial plants in riverine wetlands. These plants can grow on sandy and stony habitats on the floodplains. Particle grain size of a floodplain plays an important role in the growth of these plants. Dynamic Herbaceous Models were developed to simulate the growth dynamics of a monospecific stand of P. australis, Typha spp., and P. japonica in freshwater ecosystems. The mathematical models were formulated by Asaeda [44] and the results were validated in Czech Republic, Australia and Japan [44], U.S.A. [45], Egypt [46], and Japan [5].

In this Dynamic Herbaceous Model, meteorological data such as daily temperature and daily solar radiation are the input parameters (Figure 3). In the case of lacking meteorological data, the latitude of the study site is considered as input for calculating the temperatures and solar radiation. The model consists of five different equations for shoots, inflorescence, roots, old rhizomes, and new rhizomes [5,44]. The initial rhizome and root biomass are also given as input variables for initiation of growth. The net growth of the whole plant is the combined effect of photosynthesis, respiration, mortality and transfer of assimilated materials. 


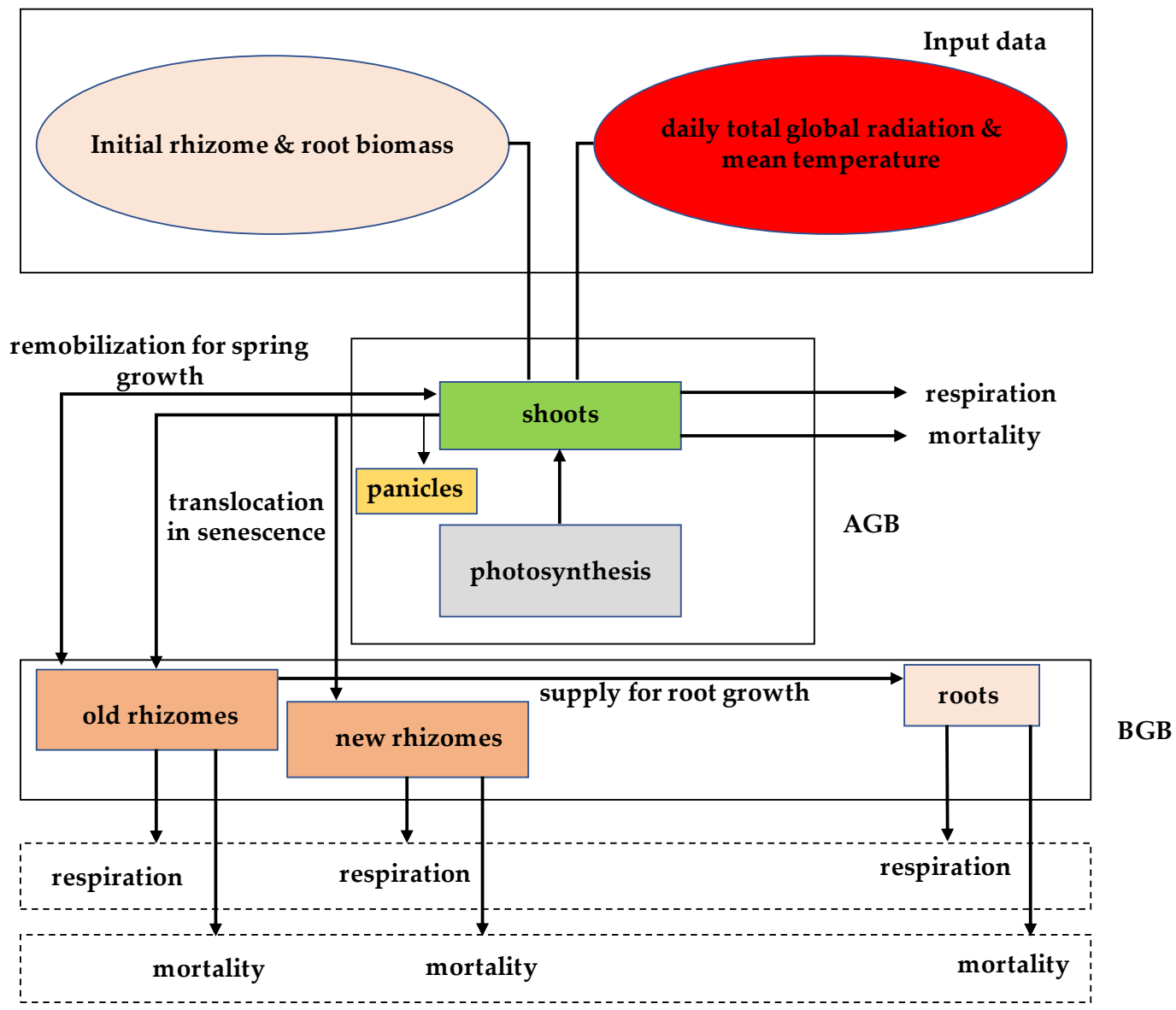

Figure 3. Schematic structure of the Dynamic Herbaceous Model.

The net production of herbaceous plant is calculated by using Equation (1).

$\begin{aligned} & \text { Net production }=\frac{d B_{T}}{d t} \\ &=\sum_{i=\text { layer }} P h(i)-\sum_{\text {organ }}(\text { Respiration })-\sum_{\text {organ }}(\text { Mortality }) \pm \sum_{\text {organ }}(\text { Translocation }),\end{aligned}$

where $\sum_{\mathrm{i}=\text { layer }} P h(i)$ is sum of layer by layer photosynthesis performed by leaves of a herbaceous plant, $\sum_{\text {organ }}($ Respiration $)$ is total loss of biomass due to respiration, $\sum_{\text {organ }}$ (Mortality) is total loss of biomass due to dead of plants organ such as shoots, inflorescence, roots, old rhizomes, and new rhizomes of herbaceous plants. $\sum_{\text {organ }}$ (Translocation) is transfer of assimilated materials. The + sign represents the upward transfer of assimilated materials from BGB to AGB and the - sign represents the downward transfer from AGB to BGB.

\subsubsection{DRIPVEM Coupled with a Dynamic Herbaceous Model}

For long-term modelling and incorporation of numerous interacting parameters with riparian vegetation succession subjected to both herbaceous plants and trees, Asaeda [8,9] developed a dynamic model which can predict the vegetation succession and interaction with floods, riparian morphology, nutrients, sediment size, etc.

Figure 4 shows the schematic diagram of DRIPVEM coupled with a Dynamic Herbaceous Model. The model consists of HYDRO, TREE, HERB, and NUTRIENTS modules with their interactive roles $[8,9]$. The HYDRO module is used to link up flood hydrology to TREE and HERB modules which occurred in the floodplain. The flushing effects of flood is also considered in the model. The TREE 
module calculates the spatial tree distribution in the floodplain by considering initial colonization after flooding. The allometric relations with diameter at breast height (DBH) and age were also included in the model to predict the biomass growth of tree species such as Salix gilgiana, Robinia pseudoacacia, and Albizia julibrissin [8,9,47]. The HERB module calculates the herbaceous plants biomass with its spatial distribution in the floodplain in which particle size, shading effects of tree canopy, as well as the nutrient interactions and effects of floods are incorporated in the model. The NUTRIENTS module depicts the soil nutrients budget by interacting atmospheric nitrogen, flood nitrogen, nitrogen release after decomposition of litter biomass, and the $\mathrm{N}$ - fixation process of rhizobium bacteria with soil in the floodplain. The outputs of DRIPVEM were validated for Japanese steep rivers [35].

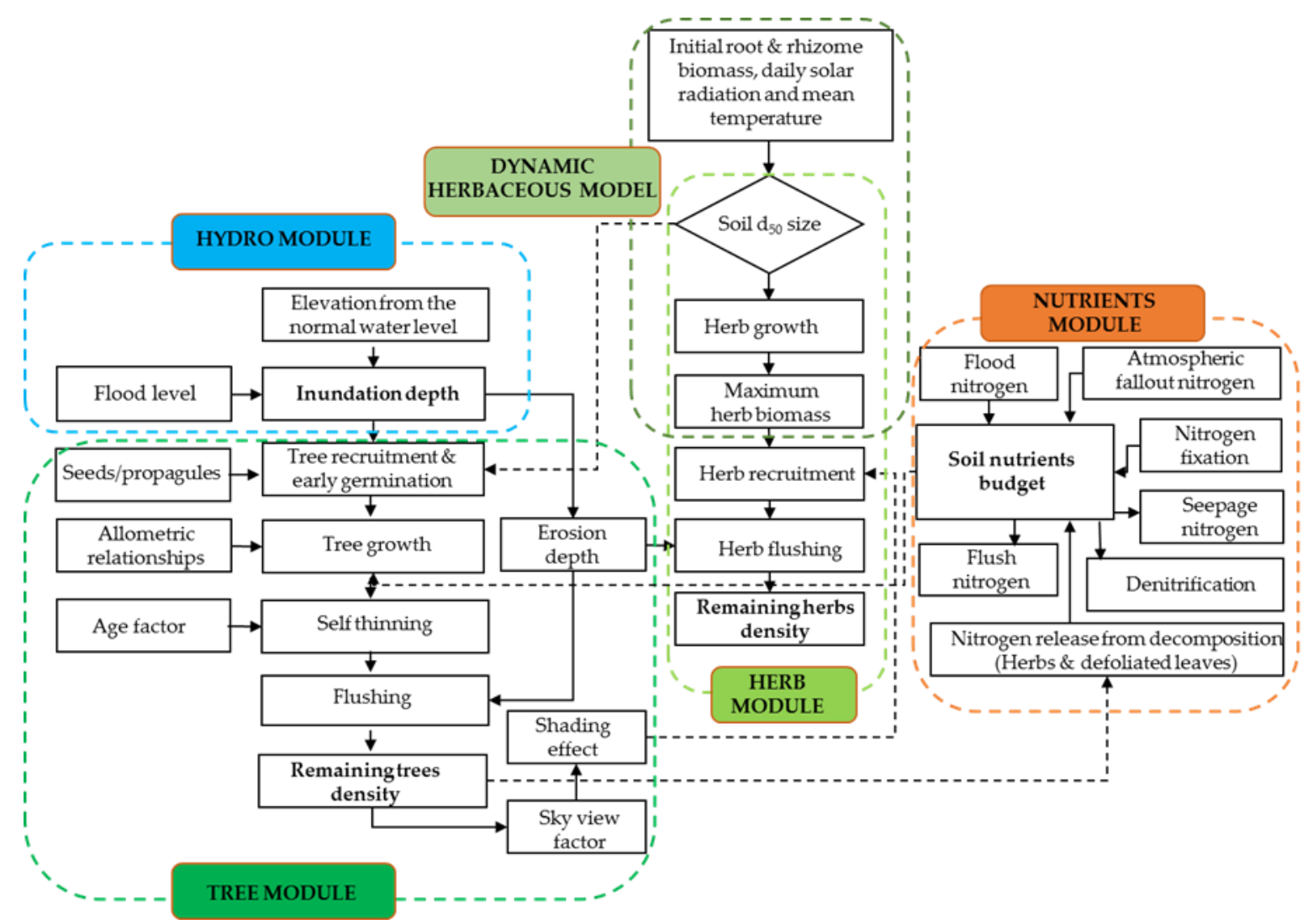

Figure 4. Schematic structure of Dynamic Riparian Vegetation Model (DRIPVEM) coupled with a Dynamic Herbaceous Model.

In the HERB module of DRIPVEM, the maximum herb biomass is one of the input parameters. In the absence of observed data of maximum herb biomass in floodplain, a Dynamic Herbaceous Model is used to calculate the maximum herbs biomass in the floodplain. The output value of maximum biomass simulated by the Dynamic Herbaceous Model transfers to HERB MODULE which is one input parameter of DRIPVEM. This is a new technique to couple the DRIPVEM model with a Dynamic Herbaceous Model to describe the vegetation growth in riparian zone (Figure 4).

\section{Results}

The historical monthly maximum flood levels (1969-2014) in Kuzuryu River study reach is shown in Figure 5a (http://www1.river.go.jp/). The riparian area is divided into $10 \times 10 \mathrm{~m}$ meshes having elevations ranges from 0 (normal water level) to $7.33 \mathrm{~m}$. The upstream riparian zone consists of the highest elevations and more than $50 \%$ riparian area composed of low elevations from 0.1 to $3 \mathrm{~m}$ (Figure 5b). 

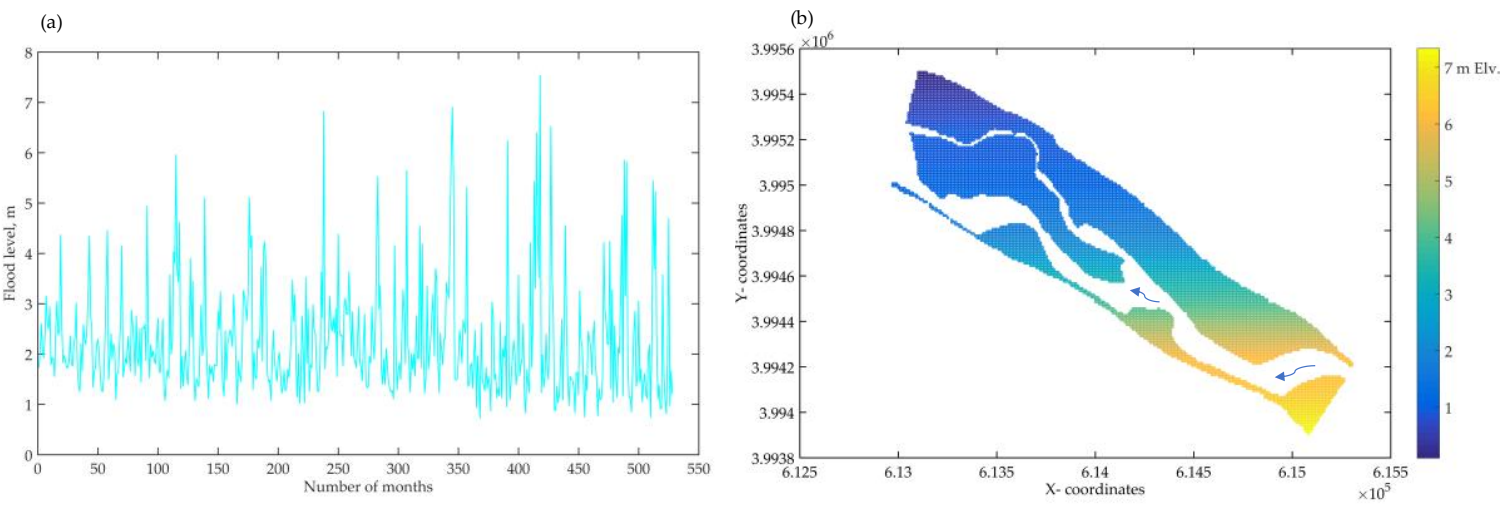

Figure 5. (a) Historical flood level (b) Floodplain elevation.

\subsection{Seasonal Growth of Herbaceous Plants}

The monthly mean observed AGB and BGB of P. japonica on the floodplain in sandy habitat is higher than gravelly habitat (Figure 6a,b). The morphology of this plant such as plant density and height of plant are higher in sandy soil compared to gravelly soil. Flood disturbance and sediment interaction in the riparian zone alter the morphological conditions of the riparian zone such that the vegetation growth changes in the floodplain. The monthly mean observed AGB was significantly higher than at the gravelly site (two sample $t$-test, $p<0.05$ ). Similarly, the monthly mean observed BGB at sandy sites was significantly higher than at the gravelly site (two sample $t$-test, $p<0.05$ ). The observed maximum AGB was $1406 \mathrm{gm}^{-2}$ at $0.13 \mathrm{~mm}$ sediment grain size (sandy site) whereas its value was $400 \mathrm{gm}^{-2}$ at $15.2 \mathrm{~mm}$ sediment grain size (gravelly site). Similarly, the observed BGB was $1147 \mathrm{gm}^{-2}$ in the sandy site and $808 \mathrm{gm}^{-2}$ in the gravelly site respectively. The AGB is easily removed subject to floods and thereafter the photosynthesis is curtailed throughout the remaining growth periods of the year, although the secondary shoots grow if the flood occurs early in the growing season $[48,49]$. The Dynamic Herbaceous Model predicted that the maximum AGBs were $1347 \mathrm{gm}^{-2}$ at the sandy site and $462 \mathrm{gm}^{-2}$ at the gravelly site. Similarly, the model predicted the maximum BGBs were $853 \mathrm{gm}^{-2}$ at the sandy site and $541 \mathrm{gm}^{-2}$ at the gravelly site. The comparison of observed and simulated AGB $\left(R^{2}=0.92\right)$ and BGB $\left(R^{2}=0.85\right)$ at sandy soil and AGB $\left(R^{2}=0.51\right)$ and BGB $\left(R^{2}=0.66\right)$ at gravelly soil (Kumagaye, Japan) are shown in Figure 6a,b.

(a)

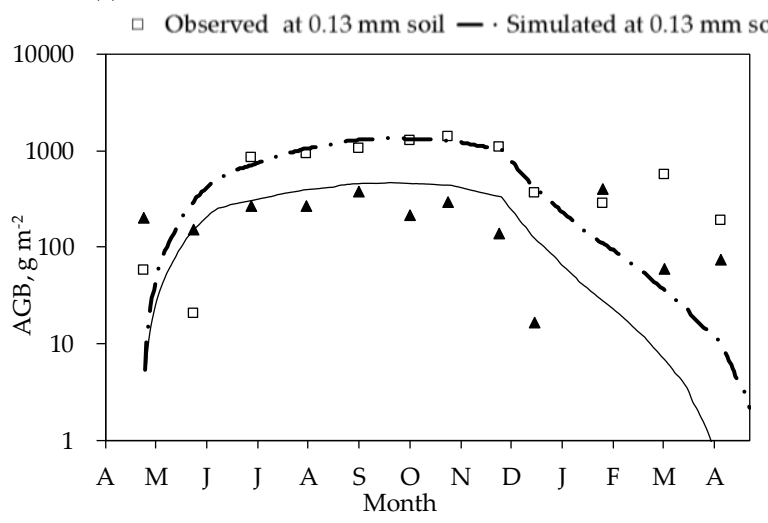

(b)

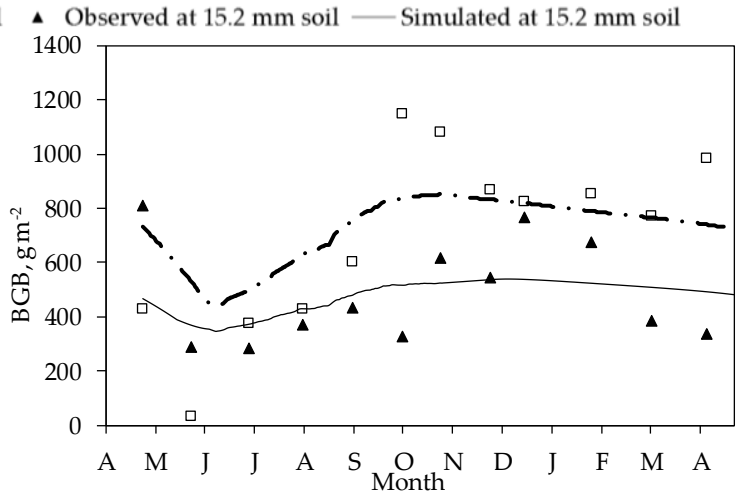

Figure 6. Observed and simulated biomass Phragmites japonica at different habitats. (a) Aboveground biomass (AGB) and (b) belowground biomass (BGB).

\subsection{Historical Evidence of Growth of Herbs and Trees in the Floodplain}

Figure 7 shows the historical aerial images in chronological sequence of development of vegetation growth in Kuzuryu river study reach from 1982 to 2018. From the historical imagery observations, 
one can notice that the sediment deposition area decreased and riparian vegetation area increased year by year. A major flood of $2144 \mathrm{~m}^{3} \mathrm{~s}^{-1}$ with a flood level of $6.82 \mathrm{~m}$ occurred in September, 1989. This major flood changed the morphology of river and increased the riparian zone coverage rapidly. After 9 years, another major flood of discharge $2517 \mathrm{~m}^{3} \mathrm{~s}^{-1}$ with a flood level of $6.9 \mathrm{~m}$ occurred in September, 1998. Similarly, a high flood of discharge $2400 \mathrm{~m}^{3} \mathrm{~s}^{-1}$ with a $6.24 \mathrm{~m}$ flood level was encountered in the study reach in October 2002 and a highest flood of discharge $3221 \mathrm{~m}^{3} \mathrm{~s}^{-1}$ with inundation level of 7.54 was encountered in October 2004 (Figure 5a). These major floods changed the morphology of the floodplain.

(a)

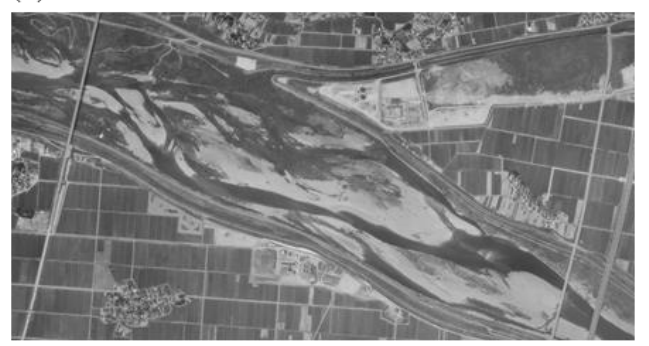

(c)

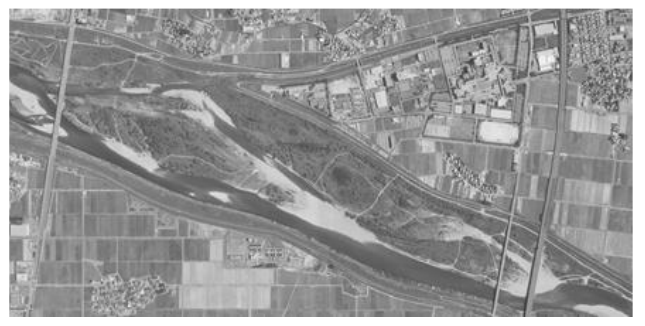

(b)

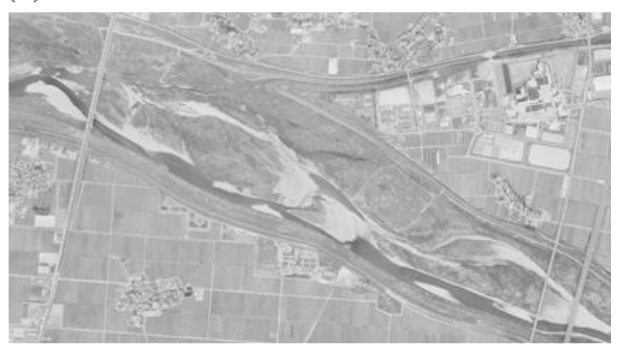

(d)

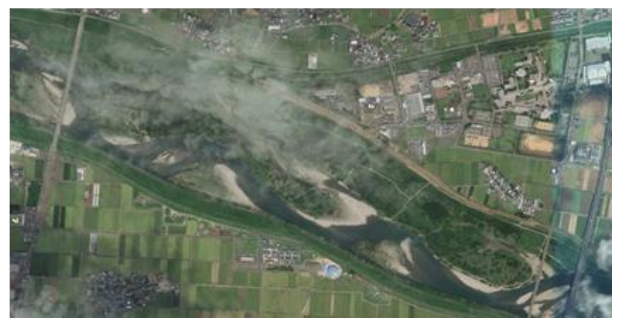

Figure 7. Historical aerial images in chronological sequence illustrating vegetation growth in Kuzuryu River, Japan: (a) 1982, (b) 1994, (c) 2004, (d) 2018 (Source: Geographical Information Authority of Japan https://mapps.gsi.go.jp/maplibSearch.do\#1 and Google Earth 2018).

\subsection{Prediction of Vegetation Growth by Using DRIPVEM Coupled with Dynamic Herbaceous Plants Model}

Figure $8 \mathrm{a}, \mathrm{b}$ shows the simulated spatial distribution of herb biomass on the floodplain after 49 years of simulation in sandy $\left(D_{50}=1 \mathrm{~mm}\right)$ and stony $\left(D_{50}=50 \mathrm{~mm}\right)$ sites. After large flood, nearly all areas of the riparian zone were inundated except for a few high elevated areas whereby they retain only herb biomass as well as the soil total nitrogen (TN). Herbs were easily washed away and soil TN concentration also decreases in flood affected areas [8]. After completing the lifecycle of herbaceous plants, the AGB undergo senescence and decompose so that nutrients were released in to the floodplain. The retained nutrients were used for the next growing seasons for herbaceous plants and creates favorable conditions for tree growth. The DRIPVEM results after 49 years of simulation showed that the spatial distribution of herbs biomass in the sandy site varied from 657 to $1124 \mathrm{~g} \mathrm{~m}^{-2}$ whereas in stony site varied from 205 to $400 \mathrm{~g} \mathrm{~m}^{-2}$. Out of 8639 meshes, 7661 meshes are covered with herbs in 2018 and the DRIPVEM generated 4224 meshes were covered with herb biomass $\left(\mathrm{R}^{2}=0.55\right)$.

Figure 9 a shows the simulated density wise spatial distribution of trees on the floodplain after 49 years of simulation in the sandy site. The density wise distribution of trees varied from 0.02 to 0.53 Nos. $\mathrm{m}^{-2}$ consisting of different ages of trees varying from 1 to 18 years old (Figure $9 \mathrm{~b}$ ). Out of 8639 meshes, 7217 meshes are covered with trees in 2018 and the DRIPVEM calculated 4224 meshes were covered with trees $\left(\mathrm{R}^{2}=0.65\right)$. The discrepancies were expected due to the external factors, for example hydraulic factors, temperature, and environmental factors change after flood events. 

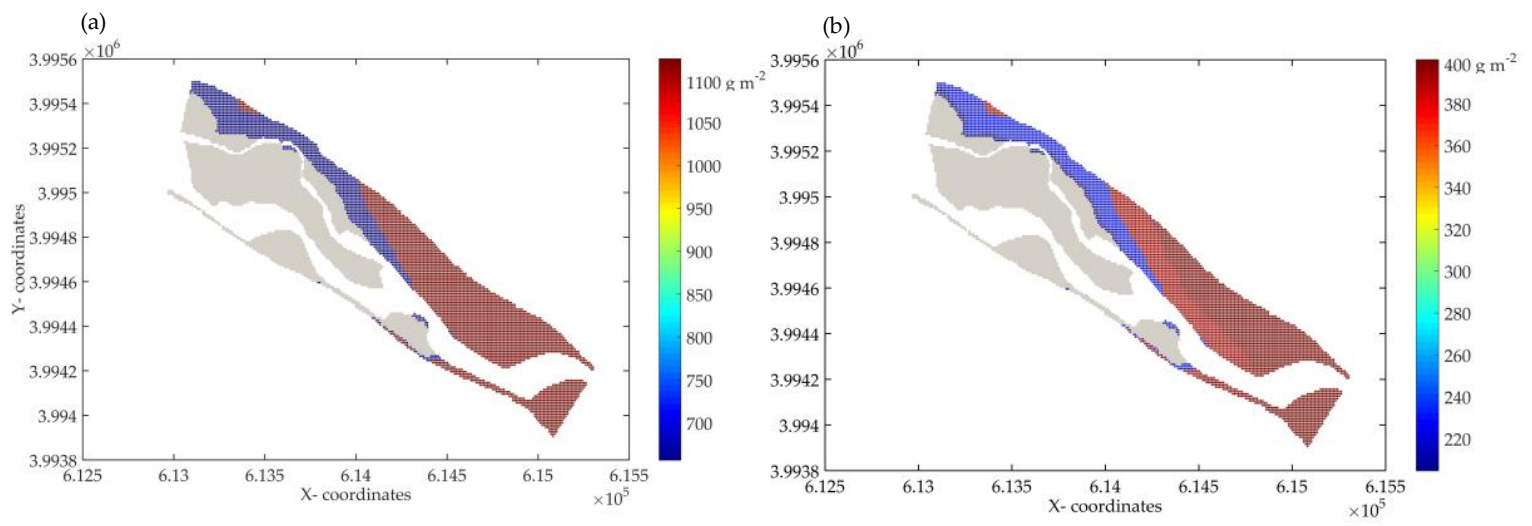

Figure 8. Simulated spatial distribution of herbs in floodplain. (a) $\mathrm{D}_{50}=1 \mathrm{~mm}$ size (b) $\mathrm{D}_{50}=50 \mathrm{~mm}$ size.
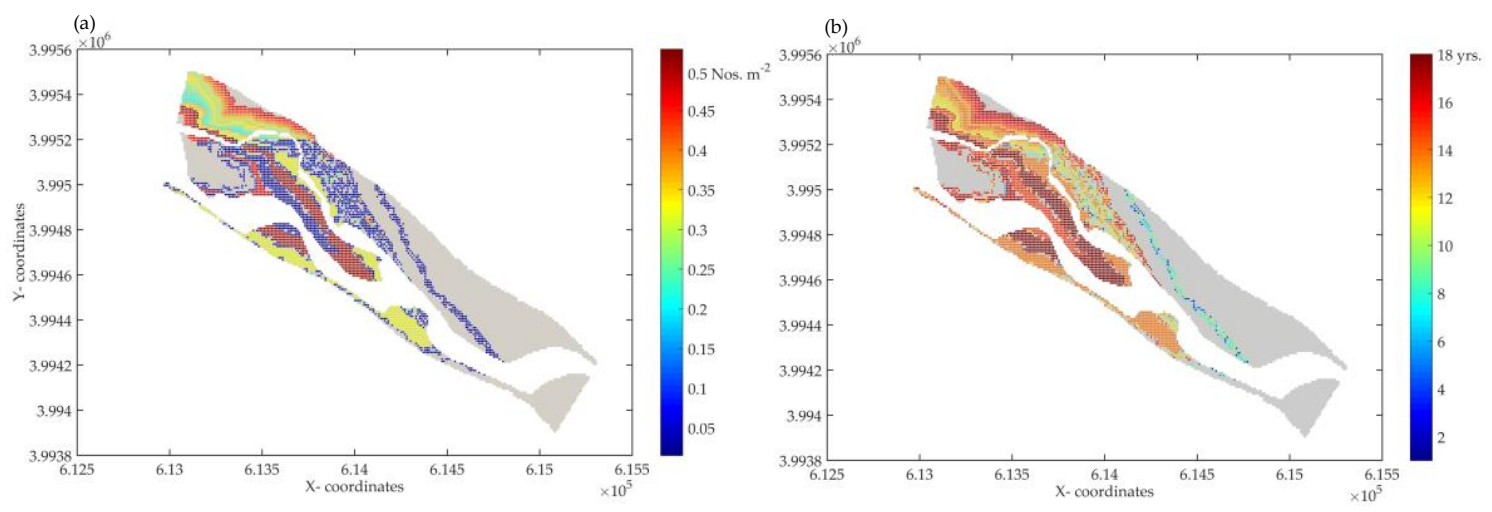

Figure 9. Simulated spatial distribution of trees in the sandy floodplain. (a) Density wise distribution and (b) age wise distribution.

\section{Discussion}

\subsection{Growth of Herbaceous Plants in the Riparian Zone}

The Dynamic Herbaceous Model calculated the net growth of the plant stand is the integral effect of photosynthesis, respiration, mortality, and translocation of assimilated materials between shoots and belowground organs $[5,44,50,51]$. The transfer between the aboveground and belowground biomass in the case of perennial plants differentiates their morphology depending on their plasticity $[48,52,53]$. The moisture and nutrients limitation in coarse sediment sites decreases the growth of plants whereas the available higher moisture and nutrients in sandy sites increases the growth of herbaceous plants so that the total biomass in fine sediment was more than coarse sediment.

The aboveground part of herbaceous plants begins in the mid spring with the expense of reserve rhizomes by the upward translocation [54]. This upward translocation continues up to early summer and rhizome biomass decreases so that aboveground biomass continuously increases. When upward translocation was near the saturation stage, photosynthesized material starts downward translocation to rhizomes reserving for next growing season. Additionally, biomass of shoots continues to grow and maximum AGB occurs at autumn [55] (Figure 7a,b). The aboveground parts die or are removed by the flood flow. The photosynthesis production is highly curtailed during the flooding period in the year, although secondary shoots grow if the flood occurs early in the growing season [49]. The sediment trapping behavior of herbaceous plants deposited sediments in the upstream of herbaceous plants and scour formed behind the vegetation with changing flow velocity profile [56]. The sediment trapped zone around the herbaceous plants [57] in the floodplain contains higher nutrients. Herbaceous plants subjected to annual floods, therefore, gradually shrinks year after year, particularly if floods occur when the plants are in active growth stage. 
The flushing of suspended sediments through dams also transported high nutrients into the downstream area [58]. These interactive relationships between flooded water, erosion or deposition area, sediment, and nutrients contributed in creating riparian zones more fertile [28], which created the favorable condition for rapid growth of riparian vegetation.

\subsection{Growth of Trees in the Riparian Zone}

The substrate texture of floodplain changes after flood flows. Thus, in case of low flow disturbance and shallow inundation, the substrate texture changes from coarse to fine, as fine sediment deposits on the top surface of floodplain [59] such that the growth of herbaceous plants are enhanced. Subjected to high flow disturbance and deep inundation, existing fine sediments of top surface of floodplain wash away exposing the underlying coarse textures on the floodplain, and suppresses the growth of herbaceous plants. Atmospheric nitrogen, nutrients release after decomposition of AGB and BGB parts of herbaceous plants [60] also supports to increase nutrients in the riparian zone, creates favorable conditions for trees growth. The vegetation was colonized after the large floods, therefore gradually covered the floodplain with trees year after year. Finally, the whole sediment deposited area was covered with herbs and mature trees.

DRIPVEM coupled with a Dynamic Herbaceous Model considered most of the physical, chemical, and biological interactive parameters, for examples flood disturbance, riparian morphology, median sediment sizes $\left(D_{50}\right)$, erosion depth, deposition areas, allometric relationships of trees growth, shading effects of trees canopy, self-thinning phenomenon, availability of nutrients in water, and sediment with riparian zone, etc. The simulated results of spatial distribution of herbs $\left(R^{2}=0.55\right)$ and trees $\left(R^{2}=0.65\right)$ by using the coupled DRIPVEM tool have an acceptable agreement.

\section{Conclusions}

The interactive parameters associated in fluvial flow, erosion and deposition area of floodplain, and nutrient availability support riparian vegetation growth in the floodplain. The long-term riparian vegetation growth in the floodplain is quantified by using mathematical models. The Dynamic Herbaceous Model can predict the maximum biomass of herbs in the floodplain, which links to DRIPVEM as an input part. The DRIPVEM coupled with the Dynamic Herbaceous Model can simulate the spatial distribution of herbs and trees in respect of biomass as well as age-wise distribution of trees in the floodplain. The potential use of this study is to predict the long-term riparian vegetation changes in floodplain. The model could be used in mixed forests in different scenarios by incorporating allometric observations of different species wise growth of trees and availability of water and sediment with nutrients on floodplains with elevation wise sediment grain sizes $\left(D_{50}\right)$ and morphology of riparian zones. This model could be very useful tool for long-term forest planning, resources management and decision making.

Author Contributions: Conceptualization and methodology, M.B.B. and T.A.; software, validation, formal analysis and writing - original draft preparation, M.B.B.; writing-review and editing M.B.B., T.A., T.F., S.M.D.H.J. and G.M.; supervision T.A.; data curation M.B.B., T.A., G.M. and J.L. All authors have read and agreed to the published version of the manuscript.

Funding: This research was supported by Grant-in-Aid for Scientific Research (B) (18KK0116) JSPS funding.

Acknowledgments: The authors would like to give thanks to Saitama University for managing the research environment. We would also like to thank to Ministry of Land, Infrastructure, Transport and Tourism, Japan for accessing historical fluvial, flood level, water quality, and climate data and also would like to give thanks to Geographical Information Authority of Japan for sequential historical images.

Conflicts of Interest: The authors declare no conflict of interest. 


\section{References}

1. Fu, B.; Li, Y.; Wang, Y.; Zhang, B.; Yin, S.; Zhu, H.; Xing, Z. Evaluation of ecosystem service value of riparian zone using land use data from 1986 to 2012. Ecol. Indic. 2016, 69, 873-881. [CrossRef]

2. Camporeale, C.; Ridolfi, L. Riparian vegetation distribution induced by river flow variability: A stochastic approach. Water Resour. Res. 2006, 42,1-13. [CrossRef]

3. Asaeda, T.; Sanjaya, K. The effect of the shortage of gravel sediment in midstream river channels on riparian vegetation cover. River Res. Appl. 2017, 33, 1107-1118. [CrossRef]

4. Zhao, H.; Yan, J.; Yuan, S.; Liu, J.; Zheng, J. Effects of Submerged Vegetation Density on Turbulent Flow Characteristics in an Open Channel. Water 2019, 11, 2154. [CrossRef]

5. Asaeda, T.; Baniya, M.B.; Rashid, M.H. Effect of floods on the growth of Phragmites japonica on the sediment bar of regulated rivers: A modelling approach. Int. J. River Basin Manag. 2011, 9, 211-220. [CrossRef]

6. Asaeda, T.; Nallaperuma, B.; Baniya, M.B.; Jayashanka, S.M.D.H. Riparian Vegetation Classification using the Dynamic Riparian Vegetation Model. In Proceedings of the E-proceedings 38th IAHR World Congress, Panama City, Panama, 1-6 September 2019.

7. Asaeda, T.; Fujino, T.; Manatunge, J. Morphological adaptations of emergent plants to water flow: A case study with Typha angustifolia, Zizania latifolia and Phragmites australis. Freshw. Biol. 2005, 50, 1991-2001. [CrossRef]

8. Asaeda, T.; Rashid, M.D.H. Modelling of nutrient dynamics and vegetation succession in midstream sediment bars of a regulated river. Int. J. River Basin Manag. 2014, 12, 123-133. [CrossRef]

9. Asaeda, T.; Rashid, M.H.; Abu Bakar, R. Dynamic modelling of soil nitrogen budget and vegetation colonization in sediment bars of a regulated river. River Res. Appl. 2015, 31, 470-484. [CrossRef]

10. Klaus, K.; Albrecht, Z. Seed Dispersal in Flood Plain Forests of Amazonia. Biotropica 2019, 26, $30-43$.

11. Lytle, D.A.; Poff, N.L. Adaptation to natural flow regimes. Trends Ecol. Evol. 2004, 19, 94-100. [CrossRef]

12. Boedeltje, G.E.R.; Bakker, J.P.; Ten Brinke, A.; Van Groenendael, J.M.; Soesbergen, M. Dispersal phenology of hydrochorous plants in relation to discharge, seed release time and buoyancy of seeds: The flood pulse concept supported. J. Ecol. 2004, 92, 786-796. [CrossRef]

13. Vogt, K.; Rasran, L.; Jensen, K. Water-borne seed transport and seed deposition during flooding in a small river-valley in Northern Germany. Flora-Morphol. Distrib. Funct. Ecol. Plants 2004, 199, 377-388. [CrossRef]

14. Asaeda, T.; Sharma, P.; Rajapakse, L. Seasonal patterns of carbohydrate translocation and synthesis of structural carbon components in Typha angustifolia. Hydrobiologia 2008, 607, 87-101. [CrossRef]

15. Lippert, I.; Rolletschek, H.; Kühl, H.; Kohl, J.-G. Internal and external nutrient cycles in stands of Phragmites australis-A model for two ecotypes. In Shallow Lakes' 98; Springer: Berlin/Heidelberg, Germany, 1999; pp. 343-348.

16. Moriuchi, K.S.; Winn, A.A. Relationships among growth, development and plastic response to environment quality in a perennial plant. New Phytol. 2005, 166, 149-158. [CrossRef]

17. Asaeda, T.; Siong, K.; Kawashima, T.; Sakamoto, K. Growth of Phragmites japonica on a sandbar of regulated river: Morphological adaptation of the plant to low water and nutrient availability in the substrate. River Res. Appl. 2009, 25, 874-891. [CrossRef]

18. Asaeda, T.; Rashid, M.H.; Kotagiri, S.; Uchida, T. The role of soil characteristics in the succession of two herbaceous lianas in a modified river floodplain. River Res. Appl. 2011, 27, 591-601. [CrossRef]

19. Brandt, S.A. Prediction of downstream geomorphological changes after dam construction: A stream power approach. Int. J. Water Resour. Dev. 2000, 16, 343-367. [CrossRef]

20. Nallaperuma, B.; Asaeda, T. Long-term changes in riparian forest cover under a dam-induced flow scheme: The accompanying a numerical modelling perspective. J. Ecohydraul. 2019, 1-7. [CrossRef]

21. Sumi, T.; Kantoush, S.A. Integrated management of reservoir sediment routing by flushing, replenishing, and bypassing sediments in Japanese river basins. In Proceedings of the 8th International Symposium on Ecohydraulics, Seoul, Korea, 12-16 September 2010; pp. 12-16.

22. Asaeda, T.; Rashid, M.H. The impacts of sediment released from dams on downstream sediment bar vegetation. J. Hydrol. 2012, 430, 25-38. [CrossRef]

23. Baniya, M.B.; Asaeda, T.; KC, S.; Jayashanka, S.M.D.H. Hydraulic Parameters for Sediment Transport and Prediction of Suspended Sediment for Kali Gandaki River Basin, Himalaya, Nepal. Water 2019, 11, 1229. [CrossRef] 
24. Gudino-Elizondo, N.; Biggs, T.W.; Bingner, R.L.; Langendoen, E.J.; Kretzschmar, T.; Taguas, E.V.; Taniguchi-Quan, K.T.; Liden, D.; Yuan, Y. Modelling Runoff and Sediment Loads in a Developing Coastal Watershed of the US-Mexico Border. Water 2019, 11, 1024. [CrossRef] [PubMed]

25. Mao, L.; Cavalli, M.; Comiti, F.; Marchi, L.; Lenzi, M.A.; Arattano, M. Sediment transfer processes in two Alpine catchments of contrasting morphological settings. J. Hydrol. 2009, 364, 88-98. [CrossRef]

26. Soler, M.; Regüés, D.; Latron, J.; Gallart, F. Frequency-magnitude relationships for precipitation, stream flow and sediment load events in a small Mediterranean basin (Vallcebre basin, Eastern Pyrenees). Catena 2007, 71, 164-171. [CrossRef]

27. Asaeda, T.; Gomes, P.I.A.; Sakamoto, K.; Rashid, M.H. Tree colonization trends on a sediment bar after a major flood. River Res. Appl. 2011, 27, 976-984. [CrossRef]

28. Gurnell, A.; Petts, G. Trees as riparian engineers: The Tagliamento River, Italy. Earth Surf. Process. Landf. 2006, 31, 1558-1574. [CrossRef]

29. Naiman, R.J.; Bilby, R.E.; Bisson, P.A. Riparian ecology and management in the Pacific coastal rain forest. Bioscience 2000, 50, 996-1011. [CrossRef]

30. Nones, M.; Di Silvio, G. Modeling of river width variations based on hydrological, morphological, and biological dynamics. J. Hydraul. Eng. 2016, 142, 4016012. [CrossRef]

31. Perona, P.; Camporeale, C.; Perucca, E.; Savina, M.; Molnar, P.; Burlando, P.; Ridolfi, L. Modelling river and riparian vegetation interactions and related importance for sustainable ecosystem management. Aquat. Sci. 2009, 71, 266. [CrossRef]

32. Davies-Colley, R.J.; Meleason, M.A.; Hall, R.M.J.; Rutherford, J.C. Modelling the time course of shade, temperature, and wood recovery in streams with riparian forest restoration. N. Z. J. Mar. Freshw. Res. 2009, 43, 673-688. [CrossRef]

33. Rivaes, R.; Rodríguez-González, P.M.; Albuquerque, A.; Pinheiro, A.N.; Egger, G.; Ferreira, M.T. Riparian vegetation responses to altered flow regimes driven by climate change in Mediterranean rivers. Ecohydrology 2013, 6, 413-424. [CrossRef]

34. García-Arias, A.; Francés, F.; Ferreira, T.; Egger, G.; Martínez-Capel, F.; Garófano-Gómez, V.; Andrés-Doménech, I.; Politti, E.; Rivaes, R.; Rodríguez-González, P.M. Implementing a dynamic riparian vegetation model in three European river systems. Ecohydrology 2013, 6, 635-651. [CrossRef]

35. Sanjaya, K.; Asaeda, T. Assessing the performance of a riparian vegetation model in a river with a low slope and fine sediment. Environ. Technol. 2017, 38, 517-528. [CrossRef] [PubMed]

36. Vargas-Luna, A.; Crosato, A.; Uijttewaal, W.S.J. Effects of vegetation on flow and sediment transport: Comparative analyses and validation of predicting models. Earth Surf. Process. Landf. 2015, 40, 157-176. [CrossRef]

37. Nepf, H.; Ghisalberti, M. Flow and transport in channels with submerged vegetation. Acta Geophys. 2008, 56, 753-777. [CrossRef]

38. Sekine, H.; Sakamoto, K.; Nishimura, T.; Asaeda, T. Development of a simulation model considering vegetation growth and flushing in Arakawa River. KSCE J. Civ. Eng. 2012, 16, 239-246. [CrossRef]

39. Benjankar, R.; Egger, G.; Jorde, K.; Goodwin, P.; Glenn, N.F. Dynamic floodplain vegetation model development for the Kootenai River, USA. J. Environ. Manag. 2011, 92, 3058-3070. [CrossRef]

40. García-Arias, A.; Francés, F. The RVDM: Modelling impacts, evolution and competition processes to determine riparian vegetation dynamics. Ecohydrology 2016, 9, 438-459. [CrossRef]

41. Salminen, H.; Lehtonen, M.; Hynynen, J. Reusing legacy FORTRAN in the MOTTI growth and yield simulator. Comput. Electron. Agric. 2005, 49, 103-113. [CrossRef]

42. Mendoza, G.A.; Vanclay, J.K. Trends in forestry modelling. CAB Rev. Perspect. Agric. Vet. Sci. Nutr. Nat. Resour. 2008, 3, 1-9. [CrossRef]

43. Pretzsch, H.; Biber, P.; Ďurský, J. The single tree-based stand simulator SILVA: Construction, application and evaluation. For. Ecol. Manag. 2002, 162, 3-21. [CrossRef]

44. Asaeda, T.; Karunaratne, S. Dynamic modeling of the growth of Phragmites australis: Model description. Aquat. Bot. 2000, 67, 301-318. [CrossRef]

45. Asaeda, T.; Hai, D.N.; Manatunge, J.; Williams, D.; Roberts, J. Latitudinal characteristics of below-and above-ground biomass of Typha: A modelling approach. Ann. Bot. 2005, 96, 299-312. [CrossRef] [PubMed]

46. Eid, E.M.; Shaltout, K.H.; Asaeda, T. Modeling growth dynamics of Typha domingensis (Pers.) Poir. ex Steud. in Lake Burullus, Egypt. Ecol. Model. 2012, 243, 63-72. [CrossRef] 
47. Asaeda, T.; Gomes, P.I.A.; Takeda, E. Spatial and temporal tree colonization in a midstream sediment bar and the mechanisms governing tree mortality during a flood event. River Res. Appl. 2010, 26, 960-976. [CrossRef]

48. Asaeda, T.; Manatunge, J.; Roberts, J.; Hai, D.N. Seasonal dynamics of resource translocation between the aboveground organs and age-specific rhizome segments of Phragmites australis. Environ. Exp. Bot. 2006, 57, 9-18. [CrossRef]

49. Asaeda, T.; Rajapakse, L. Effects of spates of different magnitudes on a Phragmites japonica population on a sandbar of a frequently disturbed river. River Res. Appl. 2008, 24, 1310-1324. [CrossRef]

50. Hootsmans, M.J.M. A growth analysis model for Potamogeton pectinatus L. In Lake Veluwe, a Macrophyte-Dominated System under Eutrophication Stress; Springer: Berlin/Heidelberg, Germany, 1994; pp. 250-286.

51. Soetaert, K.; Hoffmann, M.; Meire, P.; Starink, M.; van Oevelen, D.; Van Regenmortel, S.; Cox, T. Modeling growth and carbon allocation in two reed beds (Phragmites australis) in the Scheldt estuary. Aquat. Bot. 2004, 79, 211-234. [CrossRef]

52. McConnaughay, K.D.M.; Coleman, J.S. Biomass allocation in plants: Ontogeny or optimality? A test along three resource gradients. Ecology 1999, 80, 2581-2593. [CrossRef]

53. Funk, J.L. Differences in plasticity between invasive and native plants from a low resource environment. J. Ecol. 2008, 96, 1162-1173. [CrossRef]

54. Tursun, N.; Seyithanoglu, M.; Nezihi, F.; Ozer, I.; Arzu, E. Seasonal dynamics of soluble carbohydrates in rhizomes of Phragmites australis and Typha latifolia. Flora 2011, 206, 731-735. [CrossRef]

55. Votrubov, O.; Tylov, E.; Steinbachov, L. Phenology and autumnal accumulation of N reserves in belowground organs of wetland helophytes Phragmites australis and Glyceria maxima affected by nutrient surplus. Environ. Exp. Bot. 2008, 63, 28-38.

56. Li, J.-F.; Tfwala, S.; Chen, S.-C. Effects of Vegetation Density and Arrangement on Sediment Budget in a Sediment-Laden Flow. Water 2018, 10, 1412. [CrossRef]

57. Gomes, P.I.A.; Asaeda, T. Spatial and temporal heterogeneity of Eragrostis curvula in the downstream flood meadow of a regulated river. Ann. Limnol. Int. J. Limnol. EDP Sci. 2009, 45, 181-193. [CrossRef]

58. Kantoush, S.A.; Sumi, T.; Kubota, A.; Suzuki, T. Impacts of sediment replenishment below dams on flow and bed morphology of river. In Proceedings of the First International Conference on Coastal Zone Management of River Deltas \& Low Land Coastlines, Alexandria, Egypt, 6-10 March 2010; pp. 285-303.

59. Steiger, J.; Gurnell, A.M.; Petts, G.E. Sediment deposition along the channel margins of a reach of the middle River Severn, UK. Regul. Rivers Res. Manag. Int. J. Devoted River Res. Manag. 2001, 17, 443-460. [CrossRef]

60. Standish, R.J.; Williams, P.A.; Robertson, A.W.; Scott, N.A.; Hedderley, D.I. Invasion by a perennial herb increases decomposition rate and alters nutrient availability in warm temperate lowland forest remnants. Biol. Invasions 2004, 6, 71-81. [CrossRef]

(C) 2019 by the authors. Licensee MDPI, Basel, Switzerland. This article is an open access article distributed under the terms and conditions of the Creative Commons Attribution (CC BY) license (http://creativecommons.org/licenses/by/4.0/). 